\title{
DESENVOLVIMENTO INICIAL DO ALGODOEIRO QUANDO SUBMETIDO À COMPETIÇÃO COM GRAMÍNEAS
}

Lucas Aparecido Manzani Lisboa, Ronaldo da Silva Viana, Samuel Ferrari, Victor Garcia Venâncio, Paulo Alexandre Monteiro de Figueiredo

Universidade Estadual Paulista - UNESP, Faculdade de Ciências Agrárias e Tecnológicas, Dracena, SP. E-mail: lucasmanzani@gmail.com

\section{RESUMO}

Um dos fatores que comprometem o rendimento do algodoeiro cultivado, mesmo em cultivo em diferentes épocas de semeadura, é a interferência exercida pelas plantas daninhas. O objetivo desse trabalho foi avaliar o desenvolvimento inicial do algodoeiro quando submetido à competição com gramíneas. Foi realizado um experimento com delineamento inteiramente casualizado em esquema fatorial de $3 \times 5$, sendo elas, Urochloa brizantha cv. Marandu e Piatã e Urochloa ruziziensis; e com cinco densidades de plantio, ou seja, ausência de gramínea, 163,53; 81,79; 54,51 e 40,88 cm² para cada planta de gramínea e com cinco repetições, totalizando 75 parcelas ou vasos. Após 30 dias da semeadura foram determinados os seguintes parâmetros: ISPADAL - índice spad do algodoeiro; CEAL - condutância estomática do algodoeiro; APAL e APG - altura de planta do algodoeiro e gramínea; NFAL - número de folhas do algodoeiro; MSPAAL e MSPAG - massa seca da parte aérea do algodoeiro e gramínea; MSRAL e MSRG - massa seca de raiz do algodoeiro e gramínea. O desenvolvimento inicial do algodoeiro foi comprometido com a presença das gramíneas do gênero Urochloa. É necessário o controle de gramíneas do gênero Urochloa na cultura do algodoeiro. A espécie Urochloa ruziziensis causou mais danos na cultura do algodoeiro.

Palavras-chave: Gossypium hirsutum L.; Urochloa; matocompetição; Fisiologia vegetal.

\section{INITIAL DEVELOPMENT OF COTTON WHEN SUBMITTED TO GRASS COMPETITION}

\begin{abstract}
One of the factors that compromise the yield of cultivated cotton, even in cultivation at different sowing times, is the interference exerted by weeds. The objective of this work was to evaluate the initial development of cotton when submitted to grass competition. An experiment was carried out with a completely randomized design, in a factorial scheme of 3x5, being Urochloa brizantha cv. Marandu and Piatã and Urochloa ruziziensis and with five planting densities, that is, absence of grass, 163,53; 81.79; 54.51 and $40.88 \mathrm{~cm}^{2}$ for each grass plant and with five replications, totaling 75 plots or vessels. After 30 days of sowing, the following parameters were determined: ISPADAL - cotton spad index; CEAL - stomatal conductance of cotton; APAL and APG - plant height of cotton and grass; NFAL - number of cotton leaves; MSPAAL and MSPAG - dry mass of the aerial part of the cotton and grass; MSRAL and MSRG - dry mass of cotton and grass roots. The initial development of the cotton plant was compromised with the presence of grasses of the genus Urochloa. It is necessary the control of grasses of the genus Urochloa in the cotton crop. The Urochloa ruziziensis species caused more damage to the cotton crop.

Keywords: Gossypium hirsutum L.; Urochloa; weed competition; Vegetal physiology.
\end{abstract}

\section{INTRODUÇÃO}

Atualmente, quase que a totalidade da produção nacional de algodão (Gossypium hirsutum L.) está situada em áreas de cerrado, sendo o Estado do Mato Grosso o principal produtor (CONAB, 2017). Ao longo dos últimos anos, muitos produtores brasileiros optaram por semear algodão, não somente em primeira safra entre os meses de novembro e dezembro, mas também durante a segunda safra, entre os meses de janeiro e fevereiro, geralmente com espaçamento reduzido entre as linhas de plantio 
e com a utilização de cultivares adaptados, como por exemplo, aqueles com ciclo mais curto (RAIMONDI et al., 2017).

No entanto, um dos fatores que comprometem o rendimento do algodoeiro cultivado, mesmo em cultivo em diferentes épocas de semeadura, é a interferência exercida pelas plantas daninhas (JAKELAITIS et al., 2005). A ocorrência de plantas daninhas pode reduzir o desenvolvimento das plantas, resultando em menor produtividade. Todavia, uma maior interferência ocorre quando utilizados cultivares de ciclo longo e com espaçamentos entre linhas maiores e menor densidade populacional.

Em trabalho realizado por Raimondi et al. (2017) com a cultivar de algodoeiro FM 993 cultivada em janeiro e espaçamento entre linhas de $0,76 \mathrm{~m}$ foi verificado que o período anterior à interferência (PAI) das plantas daninhas foi de 11 dias após a emergência (DAE); e que o período crítico de prevenção à interferência (PCPI) foi entre 11 e 46 DAE, admitindo-se uma perda máxima de $5 \%$ em relação à produtividade.

Dessa forma, a cultura do algodoeiro é considerada como susceptível à competição com plantas daninhas, principalmente nas primeiras semanas após a sua emergência. Isso ocorre em função do seu hábito de desenvolvimento vegetativo, pois investe suas reservas em desenvolvimento do sistema radicular. Contudo, as mesmas plantas daninhas que competem com o algodoeiro podem ser utilizadas como plantas de cobertura para cultivos em sistema de plantio direto sobre a palha (FERREIRA et al., 2010).

Devido a disputa por espaço com as outras culturas, principalmente na busca por água e nutrientes no solo, o algodoeiro responde de maneira negativa com essa competição, que passa a afetar o seu rendimento fotossintético (NAJEEB et al., 2016), consequentemente o acúmulo de massa seca na parte aérea (OLIVEIRA et al., 2013; DEEBA et al., 2012). O entendimento nas respostas fisiológicas na cultura do algodoeiro quanto submetido à competição com outras espécies torna-se uma ferramenta importante para as tomadas de decisões para o controle dessas plantas invasoras.

Diante do exposto, esse trabalho teve por objetivo avaliar o desenvolvimento inicial do algodoeiro quando submetido à competição com espécies gramíneas.

\section{MATERIAL E MÉTODOS}

O experimento foi conduzido em Dracena, Estado de São Paulo, durante o mês de outubro de 2016, em casa de vegetação, na Faculdade de Ciências Agrárias e Tecnológicas da Universidade Estadual Paulista Júlio de Mesquita Filho. Foi utilizado o delineamento inteiramente casualizado, em esquema fatorial de $3 \times 5$ sendo: Urochloa brizantha - cultivar Marandu; Urochloa brizantha - cultivar Piatã; e Urochloa ruziziensis cultivar Ruziziensis com cinco densidades de matocompetição e cinco repetições, totalizando 75 parcelas ou vasos.

Foi realizado o plantio das sementes de algodão na profundidade de três $\mathrm{cm}$, sendo utilizada a variedade IMA 7501 WS, em vasos com capacidade volumétrica de nove $\mathrm{dm}^{3}$ e 490,6 $\mathrm{cm}^{2}$ de área, preenchidos com Argissolo proveniente da camada de 0-0,3 m, previamente peneirado e adubado com ureia - 6,13 g por vaso; superfosfato triplo $-8,15 \mathrm{~g}$ por vaso; e cloreto de potássio $-3,74 \mathrm{~g}$ por vaso. Na mesma ocasião foram plantadas, a dois $\mathrm{cm}$ de profundidade as sementes das Urochloa sp.

Durante o plantio das gramíneas foram consideradas as seguintes densidades: ausência da gramínea, ou seja, apenas o plantio do algodoeiro; baixa densidade de competição com as gramíneas, onde foi considerada a presença de três plantas de gramíneas por vaso, disponibilizando $163,53 \mathrm{~cm}^{2}$ por planta. Para as condições de média densidade de competição, foi considerada a presença de seis plantas de gramíneas por vaso, disponibilizando $81,76 \mathrm{~cm}^{2}$ por planta. Em condições de alta densidade de competição, foi considerada a presença de nove plantas de gramíneas por vaso, sendo $54,51 \mathrm{~cm}^{2}$ por planta. E para as condições de muito alta densidade de competição, foi considerada a presença de doze plantas de gramíneas por vaso, sendo $40,88 \mathrm{~cm}^{2}$ por planta. Durante o período de condução do experimento os vasos foram irrigados sempre que necessário, respeitando a capacidade de campo.

Após 30 dias do plantio foram determinadas os seguintes parâmetros: ISPADAL - índice spad do algodoeiro determinado através da leitura direta do medidor digital modelo CCM200; CEAL - condutância estomática do algodoeiro determinada pela leitura direta no aparelho porômetro modelo AP-4; APAL e APG altura de planta do algodoeiro e gramínea determinada através do uso de uma régua graduada em milímetros; NFAL - número de 
folhas do algodoeiro determinada através da contagem direta na planta; MSPAAL e MSPAG massa seca da parte aérea do algodoeiro e gramínea; MSRAL e MSRG - massa seca de raiz do algodoeiro e gramínea determinadas através da secagem da massa úmida em estufa de circulação e renovação de ar em temperatura de $65^{\circ} \mathrm{C}$ até atingirem peso constante.

Todas as variáveis foram submetidas ao teste $F(p<0,05)$ e foi aplicada a análise de regressão para as densidades de competição, onde foram testados seus modelos: linear; quadrático e cúbico (BANZATTO; KRONKA, 2013).
Foi utilizado o programa estatístico Assistat 7.7 (SILVA; AZEVEDO, 2016).

\section{RESULTADOS E DISCUSSÃO}

O índice spad do algodoeiro diminuiu de maneira quadrática quando houve a competição com as espécies $U$. brizantha cv. Marundu e $U$. ruziziensis; essa resposta negativa foi observada até no máximo com cinco e quatro plantas, respectivamente, conforme demonstrado na Figura 1

Figura 1. Índice spad do algodoeiro (ISPADAL) quando submetido à competição em diferentes densidades de gramíneas. Fonte: do autor, 2016.

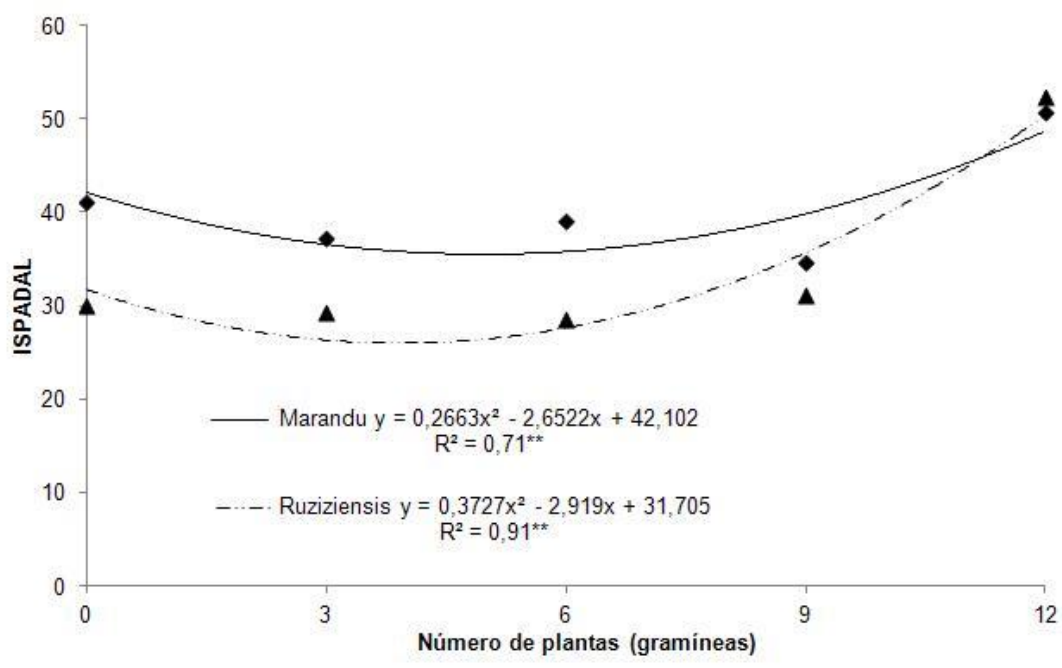

Esses resultados demonstram o efeito de compensação do algodoeiro quando foi submetido à competição por luz, o que pode ter levado ao aumento na concentração de clorofila nas suas folhas, a fim de garantir um bom desenvolvimento, de acordo com Zhang et al. (2016). Najeeb et al. (2016) quando estudaram a interferência da intensidade luminosa no desenvolvimento do algodoeiro relataram que a concentração de nitrogênio nas folhas foi reduzida em $20 \%$.
Quando o algodoeiro foi submetido à competição com a gramínea $U$. brizantha cv. Marandu a sua resposta foi de maneira quadrática descendente até o ponto máximo de oito plantas ou $61,32 \mathrm{~cm}^{2}$ de densidade de competição, o que não ocorreu com a $U$. brizantha cv. Piatã conforme demonstrado na Tabela 1.

Tabela 1. Valores médios dos parâmetros ISPADAL - índice spad do algodoeiro; CEAL - condutância estomática do algodoeiro; DCAL - diâmetro de caule do algodoeiro; APAL - altura de planta do algodoeiro quando submetido à competição com diferentes densidades de gramíneas.

\begin{tabular}{lcccc}
\hline Gramínea (G) & ISPADAL & $\begin{array}{c}\text { CEAL } \\
\left(\mu \mathrm{mol} \mathrm{m}^{-2} \mathrm{~s}^{-1}\right)\end{array}$ & $\begin{array}{c}\text { APAL } \\
(\mathrm{cm})\end{array}$ & NFAL \\
\cline { 2 - 5 } Marandu & & $* *$ & $20,37 \pm 2,98 \mathrm{~ns}$ & $5,2 \pm 0,98 \mathrm{~ns}$ \\
Piatã & $39,21 \pm 3,70 \mathrm{~ns}$ & $278,89 \pm 25,47 \mathrm{~ns}$ & $31,49 \pm 1,60 \mathrm{~ns}$ & $* *$ \\
U. ruziziensis & $* *$ & $* *$ & $* *$ & $* *$ \\
\hline
\end{tabular}

\footnotetext{
**significativo ao nível de $1 \%$ de probabilidade $(p<0,01)$ e ns - não significativo $(p>=0,05)$. Fonte: do autor, 2016.
} 
Para a $U$. ruziziensis a condutância influenciou de maneira linear negativa com o aumento na densidade de plantas competindo com o algodoeiro, conforme demonstrado na Figura 2.

Figura 2. Condutância estomática do algodoeiro (CEAL) quando submetido à competição em diferentes densidades de gramíneas.

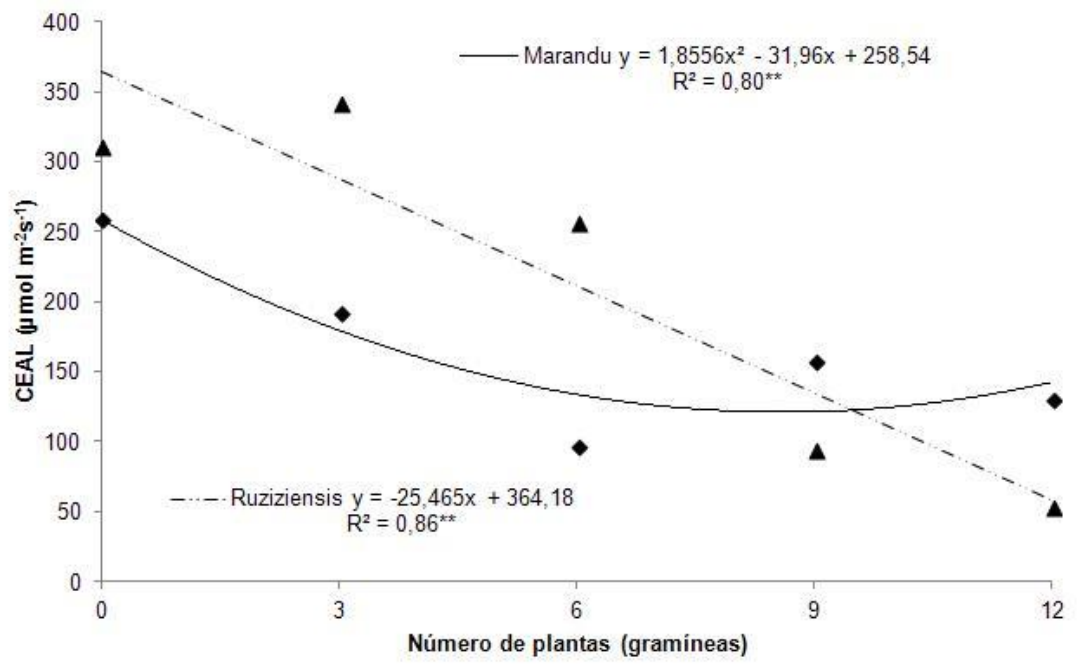

Fonte: (Autor, 2016).

Enquanto a $U$. brizantha cv. Marandu apresentou uma resposta quadrática atingindo seu ponto de máxima de competição com oito plantas aproximadamente. Esse dano não foi observado na U. brizantha cv. Piatã. Segundo Ferraz et al. (2014) a condutância estomática é um fator limitante para a fixação de carbono na massa seca da cultura do algodoeiro. Os mesmos ainda relataram que a disponibilidade de silício para a planta aumentou a sua condutância e, consequentemente, o seu desenvolvimento. Outros fatores podem influenciar a condutância estomática das plantas tais como: estresse salino
(GRACIANO et al., 2011) e hídrico (DEEBA et al., 2012); danos causados por patógenos (GUERRA et al., 2014); ou até mesmo a diversidade genética entre as cultivares de algodoeiro.

O algodoeiro responde de maneira negativa e linear somente com a presença da espécie $U$. ruziziensis, conforme demonstrado na Figura 3. O que não ocorreu com as $U$. brizantha cv. Marandu e Piatã conforme demonstrado na Tabela 1.

Figura 3. Altura da planta do algodoeiro (APAL) quando submetido à competição de Urochloa ruziziensis.

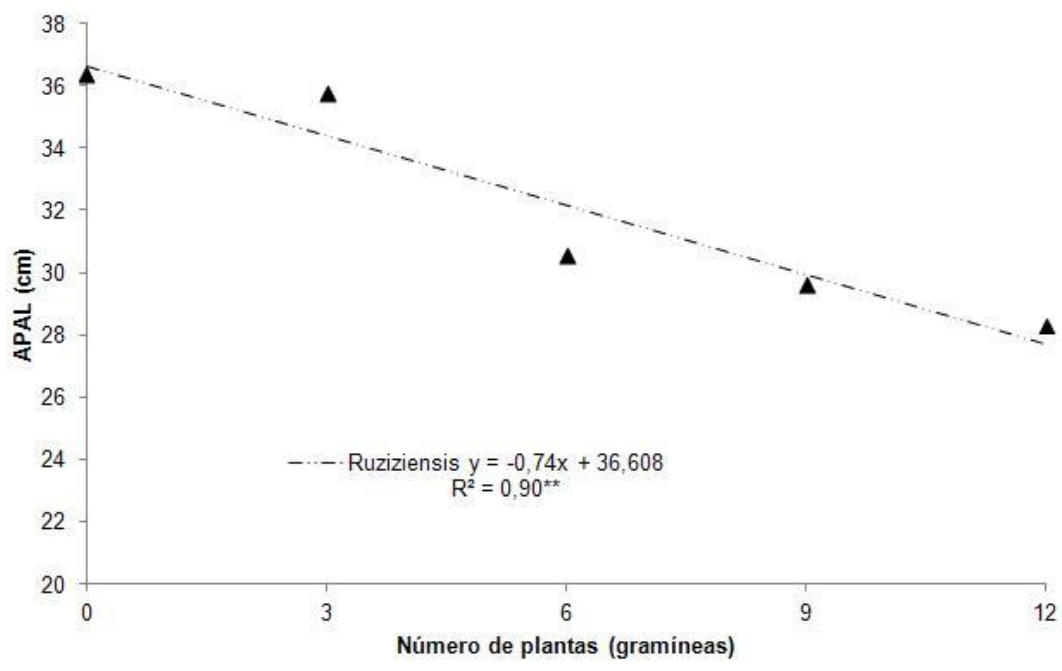

Fonte: (Autor, 2016). 
Segundo Rocha et al. (2012) estudando o crescimento do capim citronela (Cymbopogon nardus (L.) Rendle) em cultivo consorciado com algodoeiro constataram que a altura de planta não foi influenciada com a concorrência entre as espécies, o que difere com os resultados desse trabalho mostrando a necessidade de estudos mais aprofundados quanto ao comportamento do algodoeiro quando submetido a competição com outras espécies, uma vez que a espécie $U$. brizantha não influenciou o desenvolvimento da cultura (Tabela 1). Essa competição prejudica o crescimento e a arquitetura do algodoeiro, o que leva à diminuição no tamanho e número dos órgãos dos vegetais, como ocorreu com a quantidade de folhas presente no algodoeiro, conforme observado na Figura 4.

Figura 4. Número de folhas do algodoeiro (NFAL) quando submetido à competição em diferentes densidades de gramíneas.

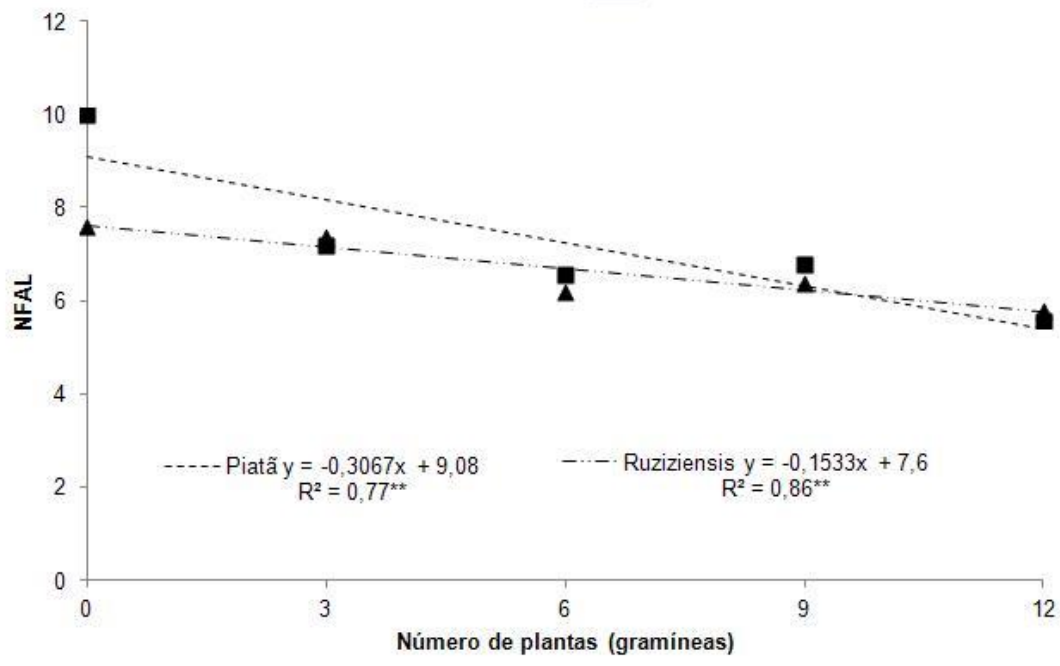

Fonte: (Autor, 2016).

Novamente o algodoeiro foi prejudicado com a competição com as espécies $U$. brizantha cv. Piatã e U. ruziziensis pois apresentaram uma resposta linearmente a esse dano, enquanto a $U$. brizantha cv. Marandu não influenciou o algodoeiro, conforme demonstrado na Tabela 1.

A influência negativa do baixo número folhas pode ser refletida no crescimento da parte aérea devido à diminuição dos fotoassimilados produzidos pelas folhas, que pode ser agravado devido ao aumento na disponibilidade de água no solo causada pelo aumento ou não do número de folhas conforme relatado por Oliveira et al. (2013) e Deeba et al. (2012). Com a diminuição do número de folhas e consequentemente na eficiência fotossintética da cultura o acúmulo de massa seca pode ter sido influenciado de maneira negativa. Esses resultados corroboram com Najeeb et al. (2016) quando estudaram a interferência da intensidade luminosa no desenvolvimento do algodoeiro, onde constataram uma redução em aproximadamente de $30 \%$ a área foliar.

Essa redução no número de folhas acarretou também uma redução na massa seca da parte aérea do algodoeiro, conforme demonstrado na Figura 5. Todas as espécies de gramínea provocaram essa redução de maneira linear, mostrando que o algodoeiro é responsivo à competição. 
Figura 5. Massa seca da parte aérea do algodoeiro (MSPAAL) quando submetido à competição em diferentes densidades de gramíneas.

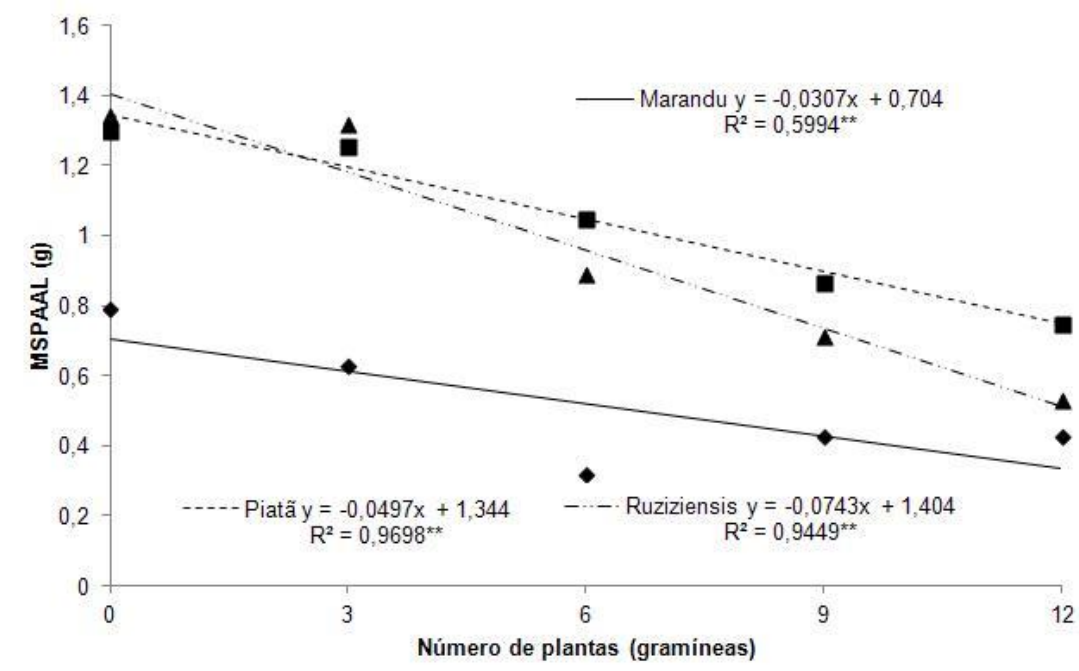

Fonte: (Autor, 2016).

Devido aos danos causados pela competição entre as espécies torna necessário o entendimento o ponto máximo de competição que as culturas apresentam e que passam a tornar uma ferramenta essencial na tomada de decisão no controle na densidade para não ocorrer o prejuízo entre as espécies. A redução da massa seca também foi observado por Oliveira et al. (2013) quando estudaram a cultura do algodoeiro herbáceo e do feijão-caupi em sistemas monocultivo e consorciado. Os mesmos ainda relataram que o acúmulo de massa seca é diretamente ligada a disponibilidade de água no solo, pois passa a exigir uma maior coluna d'água quando ocorre o aumento da parte aérea da cultura.

A competição por luz, nutrientes e água no solo passa a tornar um fator limitante para as culturas, conforme demonstrado na Figura 6. 0 algodoeiro respondeu de maneira negativa quando houve a competição com as gramíneas.

Figura 6. Massa seca de raiz do algodoeiro (MSRAL) quando submetido à competição em diferentes densidades de gramíneas.

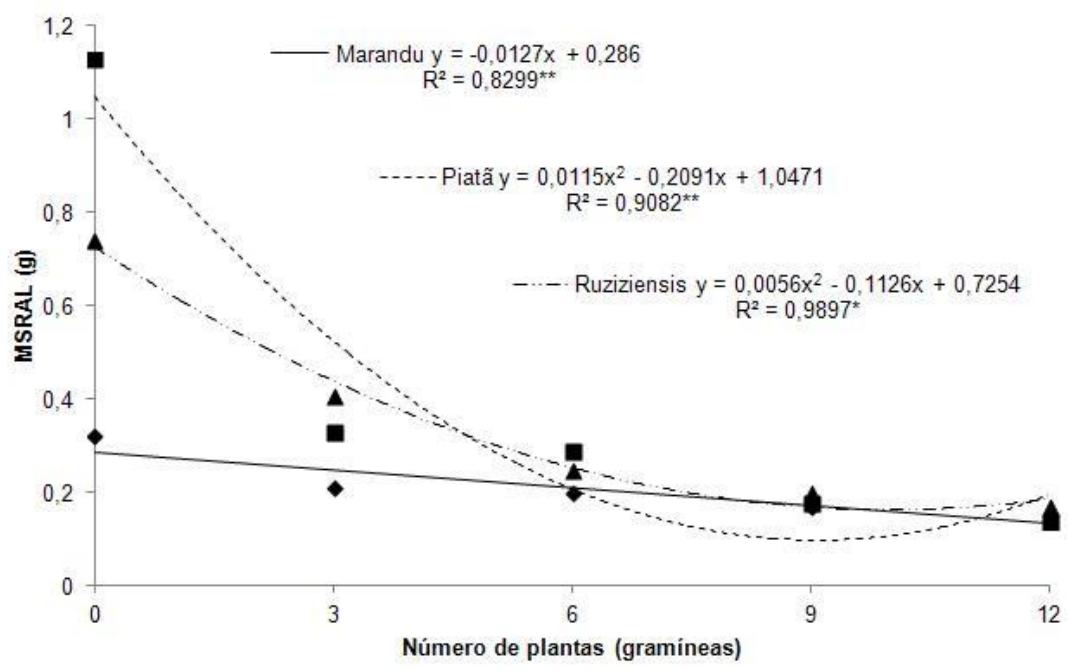

Fonte: (Autor, 2016).

Foi observado que a U. brizantha cv. Marandu prejudicou as raízes do algodoeiro de maneira linear, enquanto as gramíneas $U$. brizantha cv. Piatã e U. ruziziensis apresentaram um efeito quadrático, exibindo seus pontos máximos de danos com nove e dez plantas, ou 54,51 e $49,06 \mathrm{~cm}^{2}$ para cada planta daninha, respectivamente. 
É notória a competição entre as espécies estudadas. As raízes do algodoeiro por serem pivotantes, necessitam de um substrato mais profundo para seu desenvolvimento, o que nas fases iniciais do seu crescimento se resume apenas nas camadas mais superficiais do solo, que passa a sofrer um aumento na competição com outras espécies. Isso ocorre principalmente com as gramíneas, que possuem raízes fasciculadas e ficam em camadas mais superficiais do solo (DIÓGENES et al., 2016; SILVA et al., 2016).

Com o aumento na densidade de plantas da espécie $U$. ruziziensis, a sua altura respondeu de maneira negativa conforme a Figura 7.

Figura 7. Altura de planta da Urochloa ruziziensis (APG) em diferentes densidades de competição.

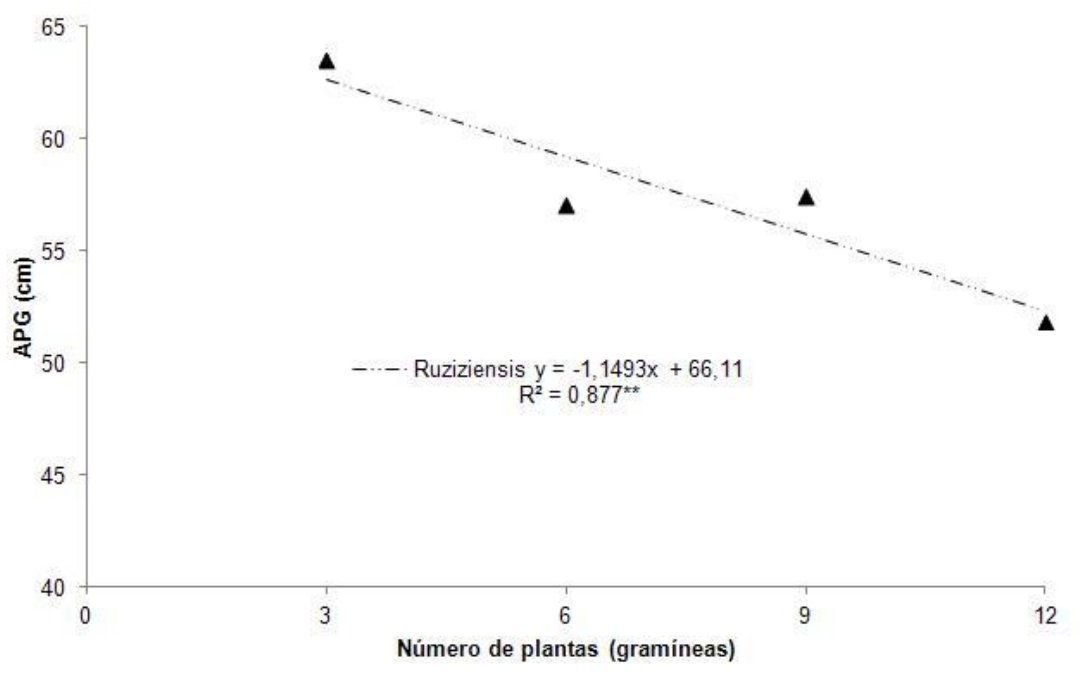

Fonte: (Autor, 2016).

Esse efeito não foi observado com as $U$.

brizantha conforme denotado na Tabela 2.

Tabela 2. Valor médio do parâmetro APG - altura de planta das gramíneas sob diferentes densidades de plantio.

\begin{tabular}{lccc}
\hline Gramínea $(\mathrm{G})$ & APG $(\mathrm{cm})$ & MSPAG $(\mathrm{g})$ & MSRG $(\mathrm{g})$ \\
\cline { 2 - 4 } Marandu & $52,59 \pm 3,40 \mathrm{~ns}$ & $* *$ & $* *$ \\
Piatã & $77,43 \pm 2,04 \mathrm{~ns}$ & $* *$ & $* *$ \\
U. ruziziensis & $* *$ & $* *$ & $* *$
\end{tabular}

**significativo ao nível de $1 \%$ de probabilidade $(p<0,01)$ e ns - não significativo ( $p>=0,05)$. Fonte: (Autor, 2016).

Esse resultado demonstra que 0 crescimento dessa espécie de gramínea foi maior; e que exigiu do algodoeiro (Tabela1) um gasto de energia para competir com a mesma, culminando no efeito de estiolamento. Peri et al. (2007) relataram que o estiolamento é uma resposta das plantas quando sombreadas, proporcionando uma nova arquitetura morfológica da planta e ocasionado um alongamento do caule, colmos ou pecíolos foliares. Galzerano et al. (2013) também relataram esse fenômeno causado pelo sombreamento sobre as gramíneas.

Com o aumento na densidade das gramíneas era esperado um efeito quadrático para a produção da sua massa seca da parte aérea, pois todas responderam de maneira linear positiva, mostrando que mesmo com uma alta competição onde foi disponibilizada uma área de $40,88 \mathrm{~cm}^{2}$, não foi o suficiente para causar algum dano no seu desenvolvimento, conforme demonstrado na Figura 8. Vale relembrar que esse efeito não foi observado na cultura do algodoeiro, pois mesmo em baixa competição, ou seja, com $163,53 \mathrm{~cm}^{2}$ para as gramíneas foi observada uma resposta negativa no seu desenvolvimento (Figura 5). 
Figura 8. Massa seca da aérea das gramíneas (MSPAG) em diferentes densidades de competição.

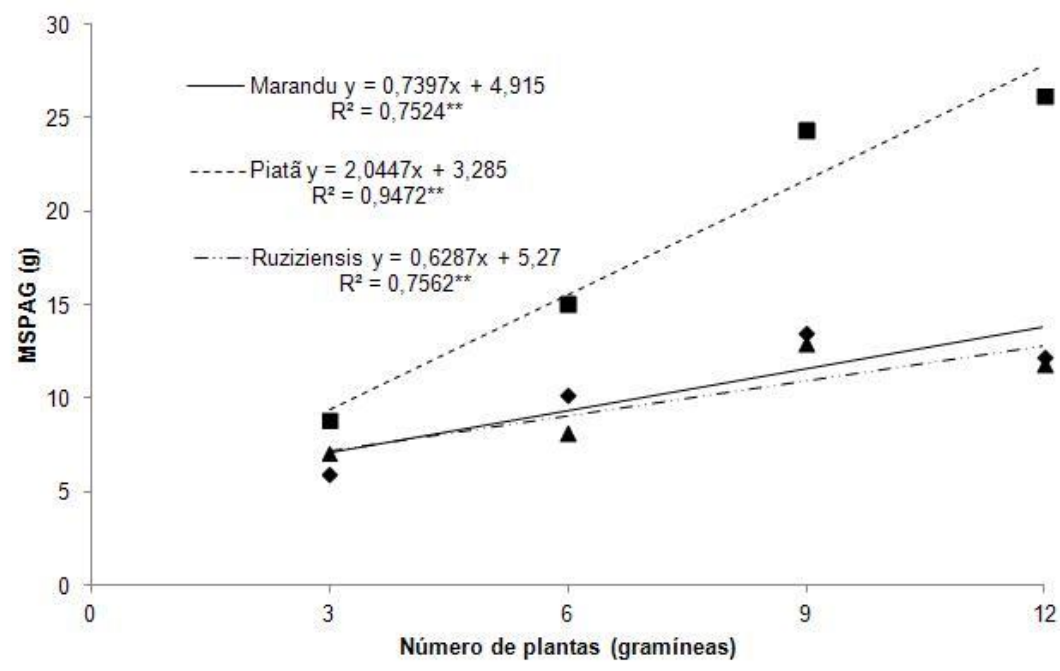

Fonte: (Autor, 2016).

Freitas et al. (2013) quando estudaram o cultivo do milho consorciado com $U$. ruziziensis constataram que a densidade de plantio da cultura influenciou no desenvolvimento da gramínea, que de maneira análoga as Urochloa sp.. No presente trabalho a cultura se desenvolveu em densidade alta e consequentemente afetou o crescimento do algodoeiro.

Segundo Silva et al. (2013) estudando desempenho da $U$. ruziziensis consorciada com a cultura do soja observaram esse efeito de competição entre as espécies principalmente pela disputa da luz, pois essa interferência limita a taxa fotossintética, resultando numa diminuição da massa seca das culturas sob competição.

Para o desenvolvimento das raízes gramíneas foi observada uma resposta quadrática em todas as espécies, onde o fator densidade de competição na gramínea $U$. ruziziensis apresentou um máximo desenvolvimento até dez plantas ou $49,06 \mathrm{~cm}^{2}$ para cada planta, enquanto para a U. brizantha cv. Marandu seu ponto de máxima foi de oito plantas ou $61,32 \mathrm{~cm}^{2}$. Para a Piatã foi de onze plantas ou $44,60 \mathrm{~cm}^{2}$, conforme demonstrado na Figura 9.

Figura 9. Massa seca de raiz das gramíneas (MSRG) em diferentes densidades de competição.

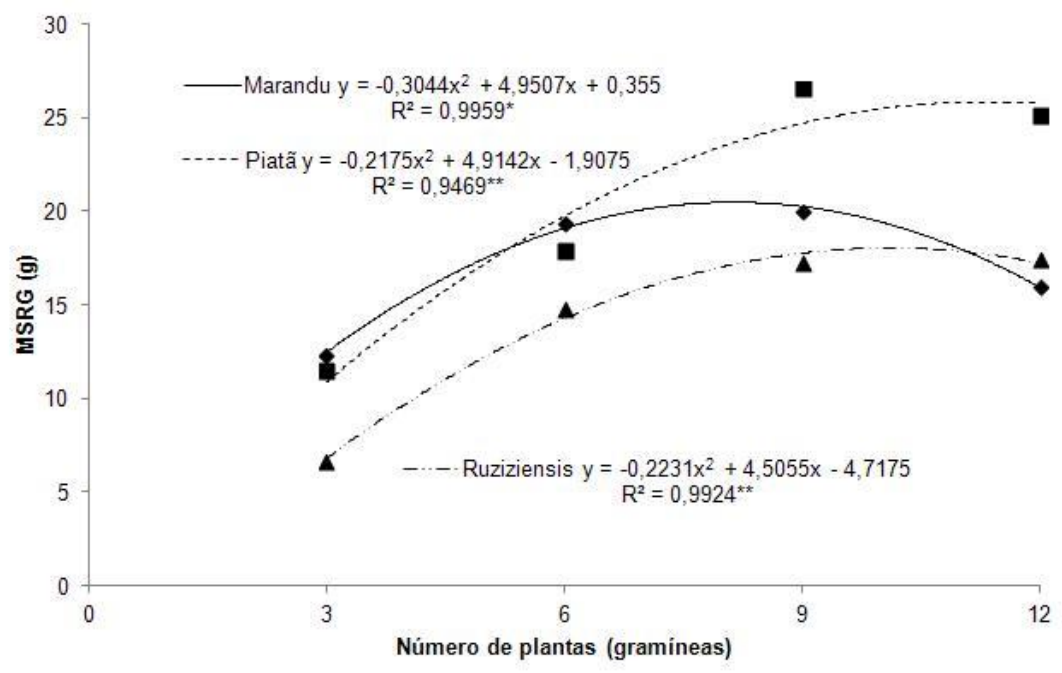

Fonte: (Autor, 2016).

O efeito já era esperado, pois com o maior número de plantas proporcionou maior massa de raiz. Dessa forma, a densidade de plantas invasoras não influenciou de maneira negativa o desenvolvimento vegetal. 
Um bom desenvolvimento de raiz é fundamental para o estabelecimento da cultura no seu substrato, garantindo maior absorção de nutrientes e água, o que pode proporcionar maior desenvolvimento da parte aérea. As plantas com maior índice de raízes no solo garante maior resistência ao estresse hídrico em períodos de veranico (CASTRO et al., 2009). Esse efeito danoso causado pela competição entre mesmas espécies ou entre espécies diferentes foi bem definido, conforme demonstrado na Tabela 1. O desenvolvimento das raízes do amendoim foi prejudicado com competição por espaço com as gramíneas. $O$ entendimento das respostas das culturas sob o efeito da intensidade da matocompetição é importante para tomada de decisões para controle das plantas invasoras, a fim de garantir o máximo de produtividade.

\section{CONCLUSÃO}

O desenvolvimento inicial do algodoeiro foi comprometido com a presença das gramíneas do gênero Urochloa. A espécie Urochloa ruziziensis causou mais danos na cultura do algodoeiro. É necessário o controle de gramíneas do gênero Urochloa na cultura do algodoeiro.

\section{REFERÊNCIAS}

BANZATTO, D. A.; KRONKA, S. N. Experimentação agrícola. 4. ed. Funep, 2013. 237p.

CASTRO, E. M.; PEREIRA, F. J.; PAIVA, R. Histologia vegetal: estrutura e função de órgãos vegetativos. Lavras: Universidade Federal de Lavras, 2009. 234 p.

CONAB. Central de informações agropecuárias. Algodão 2017. Disponível em: <https://www.conab.gov.br/conteudos.php?a=1 253\& $\mathrm{t}=>$. Acesso em: 06 jun. 2017.

DEEBA, F.; PANDEY, A. K.; RANJAN, S.; MISHRA, A.; SINGH, R.; SHARMA, Y. K.; SHIRKE, P. A.; PANDEY, V. Physiological and proteomic responses of cotton (Gossypium herbaceum L.) to drought stress. Plant Physiology and

Biochemistry, Paris, v.53, n.4, p.6-18, 2012. http://dx.doi.org/10.1016/i.plaphy.2012.01.002

DIÓGENES, L. C.; NOGREGA, J. C. A.; NÓBREGA, R. S. A.; ANDRADE JUNIOR, A. S.; SILVA, J. L.; ROCHA MATIAS, S. S. R.; SANTOS, G. G. Resistência à penetração e atributos químicos em um latossolo do Piauí sob monocultivos e consórcio de gramíneas irrigados. Irriga, Botucatu, v.1, n.1, p. 181-195, 2016.

http://dx.doi.org/10.15809/irriga.2016v1n1p181$\underline{195}$

FERREIRA, A. C. B.; LAMAS, F. M.,I.; CARVALHO, M. C. S.; SALTON, J. C.; SUASSUNA, N. D.

Produção de biomassa por cultivos de cobertura do solo e produtividade do algodoeiro em plantio direto. Pesquisa Agropecuária Brasileira, v.45, n.6, p.546-553, 2010.

FERRAZ, R. L.S.; BELTRÃO, N. E.M.; MELO, A. S.; MAGALHÃES, I. D.; FERNANDES, P. D.; ROCHA, M. $S$. Trocas gasosas e eficiência fotoquímica de cultivares de algodoeiro herbáceo sob aplicação de silício foliar. Semina: Ciências Agrárias, Londrina, v.35, n.2, p.735-748, 2014. http://dx.doi.org/10.5433/1679$\underline{0359.2014 v 35 n 2 p 735}$

FREITAS, R. J.; NASCENTE, A. S.; SANTOS, F. L. S. População de plantas de milho consorciado com Urochloa ruziziensis. Pesquisa Agropecuária Tropical, Goiânia, v. 43, n. 1, p. 79-87, 2013. http://dx.doi.org/10.1590/S1983$\underline{40632013000100011}$

GALZERANO, L.; MALHEIROS, E.B.; RAPOSO, E.; MORGADO, E.S.; RUGGIERI, A.C. Características morfogênicas e estruturais do capim-xaraés submetido a intesidades de pastejo. Semina: Ciências Agrárias, Londrina, v. 34, n. 4, p. 18791890, 2013. http://dx.doi.org/10.5433/1679$\underline{0359.2013 v 34 n 4 p 1879}$

GRACIANO, E.S.A.; NOGUEIRA, R.J.M.C.; LIMA, D.R.M.; PACHECO, C.M.; SANTOS, R.C.

Crescimento e capacidade fotossintética da cultivar de amendoim BR 1 sob condições de salinidade. Revista Brasileira de Engenharia Agrícola e Ambiental, Campina Grande, v.15, n.8, p.794-800, 2011.

http://dx.doi.org/10.1590/S1415$\underline{43662011000800005}$

GUERRA, A.M.N.M.; RODRIGUES, F.A.; LIMA, T.C.; BERGER, P.G.; BARROS, A.F.; SILVA, Y.C.R. Capacidade fotossintética de plantas de algodoeiro infectadas por ramulose e supridas com silício. Bragantia, Campinas, v. 73, n. 1, p.5064, 2014.

http://dx.doi.org/10.1590/brag.2014.010 
JAKELAITIS, A.; SILVA, A.A.; FERREIRA, L.R.; SILVA, A.F.; PEREIRA, J.L.; VIANA,R.G. Efeitos de herbicidas no consórcio de milho com Brachiaria brizantha. Planta Daninha, v. 23, n. 1, p. 69-78, 2005. http://dx.doi.org/10.1590/S010083582005000100009

MIRANDA, J. H.; BÉRGAMO, L. R.; REIS, J. B. R. S.; CRUCIANI, D. E.; DUARTE, S. N. Distribuição da concentração de potássio no solo em lisímetros cultivados com amendoim. Engenharia Agrícola. Jaboticabal, v. 30, n. 2, p. 253-263, 2010. http://dx.doi.org/10.1590/S0100$\underline{69162010000200007}$

NAJEEB, U.; BANGE, M. P.; ATWELL, B. J.; TAN, D. K. Y. Low incident light combined with partial waterlogging impairs photosynthesis and imposes a yield penalty in cotton. Journal of Agronomy and Crop Science, v.202, p. 331-341, 2016. http://dx.doi.org/10.1111/iac.12164

OLIVEIRA, S. R. M.; ANDRADE JÚNIOR, A. S.; RIBEIRO, J. L.; BARROS, M. A. Coeficientes de cultura do algodão herbáceo e do feijão-caupi em sistemas monocultivo e consorciado. Revista Brasileira de Agricultura Irrigada, Fortaleza, v.7, n.3, p.191-200, 2013.

http://dx.doi.org/10.7127/rbai.v7n300015

PERI, P.L.; LUCAS, R.J.; MOOT, D.J. Dry matter production, morphology and nutritive value of Dactylis glomerata growing under different light regimes. Agroforestry Systems. Dordrecht, v. 70, p. 63-79, 2007. http://dx.doi.org/10.1007/s10457-007-9029-x

RAIMONDI, M. A.; OLIVEIRA JUNIOR, R.S.; CONSTANTIN, J.; FRANCHINI, L.H.M.; BLAINSKI, E.; RAIMONDI, R.T. Weed interference in cotton plants grown with reduced spacing in the second harvest season. Revista Caatinga, v.30, n.1, p. 112, 2017. http://dx.doi.org/10.1590/198321252017v30n101rc

ROCHA, H.C.R.; ALVARENGA, C.D.; GIUSTOLIN, T.A.; BOMFIM, R. da S. B. G.; SOUZA, M.D.C.; SARMENTO, H.G.S.; BARBOSA, M.G. Crescimento, produção de fitomassa e teor de óleo essencial de folhas de capim citronela (Cymbopogon nardus (L.) Rendle) em cultivo consorciado com algodoeiro colorido no semiárido mineiro. Revista Brasileira de Plantas Medicinais, Botucatu, v.14, n.esp., p.183-187, 2012.
http://dx.doi.org/10.1590/S1516$\underline{05722012000500010}$

SILVA, F. A. S.; AZEVEDO, C. A. V. The Assistat Software Version 7.7 and its use in the analysis of experimental data. African Journal Agriculture Resarch, v. 11, n. 39, p. 3733-3740, 2016. http://dx.doi.org/10.5897/AJAR2016.11522

SILVA, T. L.; AGUIAR NETTO, A. O.; GONZAGA, M. S. I.; PACHECO, E. P.; LUCAS, A. A. T. Intervalo Hídrico Ótimo utilizado como indicador da qualidade física do solo em perímetro irrigado. Revista Agrogeoambiental, Pouso Alegre, v.8, n.4, p.71-81, 2016. http://dx.doi.org/10.18406/2316$\underline{1817 v 8 n 42016907}$

SILVA, W. B.; PETTER, F. A.; LIMA, L. B.; ANDRADE, F. R. Desenvolvimento inicial de Urochloa ruziziensis e desempenho agronômico da soja em diferentes arranjos espaciais no cerrado MatoGrossense. Bragantia, Campinas, v. 72, n. 2, p.146-153,

2013.

http://dx.doi.org/10.1590/S0006-

$\underline{87052013000200006 .}$

ZHANG, Y-L.; YI, X-P.; ZHANG, W-F.; CHOW, W.S.; HU, Y-Y.; ZHANG, C.; ZHAN, D-X. Photoprotection of Cotton in the Field. In: ABDURAKHMONOV, I.Y. (Ed.). Cotton Research. Intech, 2016. Cap. 3. p. 45-62. http://dx.doi.org/10.5772/64049

Recebido para publicação em 07/06/2017

Revisado em21/11/2017

Aceito em 24/01/2018 